\title{
Лиминални културни обрасци (македонската парадигма на 19 век)
}

\author{
Катица Куулавкова
}

Народната култура на 19 век го задржува почетниот модел на народна култура на Средниот и Доцниот Среден век (карактеристичен за Балканот), но вклучува и елементи својствени за новиот социјален амбиент. Таа претставува традиционален културен образец со доминантно архаична, паганска, ритуалномагиска и гротескно-реалистична слика на светот, за разлика од образецот на: 1) црковната култура која е делумно учена и висока, но и доктринарна, јазично туѓа и морално селективна; од 2) учената световна култура, која е рационална и просветителска, и од 3) новата граѓанска (староградска) култура, која е елитна и прозападна. Сите овие културни обрасци не се подвоени строго, затоа што се заемно сензибилни, што пак води до формирање на лиминалнии хибридни културни обрасци и идентитети. Во нив се меша фолклорното со елитното, ритуалното со урбаното, сакралното/црковното со световното/профаното, културното со националното.

Македонските преродбеници се парабола на транзицискиот општествен амбиент, на постколонијалниот (постотомански) цивилизациски исчекор, на пасионираниот проект да се архивира (запише) фолклорот и, конечно, на христијанската свест која постепено се преобразила во етнокултурна самосвест (за разлика од етноцентричноста на грчката и бугарската свест). Тие сфаќаат дека ни преданието и митот се историја, ни историјата е предание и мит. Таква е констелацијата во којашто тие ја инсталираат новата парадигма на толкување на историјата и културата.

Клучни зборови: народна култура, фолклоризам, карневализам, intentio liminalis, лиминални обрасци, гранични зони, трета култура, културен супстрат, Северна Македонија

\section{1.}

Еволуцијата на културите се поттикнува кога се создадени услови за преодни, гранични или лиминални културни обрасци. Да 
потсетиме, терминот лиминален потекнува од латинскиот збор limen, кој означува праг, премин на границата, воспоставување врска меѓу два простора, меѓу две култури. Тој преоден идентитетски простор е не само хибриден, туку и дијалогичен. Тој укажува на фактот дека во сите облици на „високоинтелектуалната, рафинирана култура“, се наоѓа по некоја трага од архаичниот супстрат на културно-историскиот процес, сведоштво за постоењето на една трајна „исконска структура“ (Gurevič 1987: 152) и (паганска) „матрица на свеста“ (Gurevič 1987: 344). Штом на историската сцена стапи некоја маркантна дијалошка форма на култура, значи дека публиката, па и општествениот интерес се заситени од стариот и традиционален систем и дека е дојдено време за артикулација на нов, авангарден културен израз. Како ментален простор (Ruthner 2019), лиминалноста создава привид за категоријална и идентитетска конфузија, но реално го поттикнува културниот развој и, заправо, е важна индиција на културната еволуција. Во културната сфера, преминот од еден во друг културен образец се зачнува на индивидуално рамниште, но се проширува на колективно, опфаќајќи цели културни заедници.

Културата е територијална и го носи поривот да се движи, да ги преминува границите, да гради нови облици како реплика на старите облици, да ги меша облиците и да создава некои нови, трети културни простори. Така се создаваат лиминалните или гранични културни практики. Тие гранични практики би можеле поверно да ја опишат културната еволуција и историја одошто чистите и затворени во себе облици. Кога се бира меѓу изолацијата или контактот меѓу културните практики, изборот оди во прилог на контактот. Граничните културни практики генерираат нови културни и метакултурни парадигми. По дефиниција, третата култура е варијанта на хибриден „трет простор“ (Bhabha 1998: 210), кој излегува од рамките на некој доминантен и наметнат центризам (не само европоцентризам!). Таа не е ни прва, ни друга, туку нешто помеѓу двете, затоа што контактот меѓу културните обрасци ги менува сите кои се во заемен, интеркултурен дијалог. Нешто слично се случува и со образецот на „поп-елитната култура“ во современиот глобален свет, создавајќи нов, хибриден културен и творечки простор (Ќулавкова 2016: 25).

Секој препознатлив и доминантен културен облик, во даден историски миг, претставува репер по однос на којшто ќе се оформи некој нов културен облик. И антитрадиционалните поетики со тек на време воспоставуваат нов континуитет и нова традиција. Теориски гледано, историјата познава две носечки тенденции при смената на културните обрасци: а) традиционализам (следење на традицијата) и б) антитрадиционализам (иницирање современи и модерни обрасци). 
Таквиот антагонизам се рефлектира и во областа на книжевноста и уметноста, каде што се забележува, од историска дистанца, ритмичко повторување на тенденциите за и против традицијата (процеси на автоматизација и дезавтоматизација на владејачките поетики). Но, во стварноста, на микро книжевен и културен план, еволуцијата нуди секогаш и некоја мешана, гранична и трета опција.

Доколку традиционалистичката тенденција може да се поистовети со основната интенција да се сочува архаичниот супстрат на културниот идентитет (почетниот и традиционален модел), во антитрадиционалистичката тенденција превладува основната интенција да се карневализира доминантниот културен образец преку неговиот контакт со други културни идентитети и практики. Таквиот интеркултурен дијалог, пак, отвора можност за своевидна трета развојна интенција, што би можеле да ја наречеме гранична интенција или intentio liminalis. Таа не ги урива постојните обрасци, туку ги модифицира и воведува други гранични културни идентитети. Интеркултурниот дијалог создава извесни прекумерно детерминирани лиминални културни идентитети и практики.

\section{2.}

Поделбата на средновековната култура, од т.н. „темно време“ од 6-13 век, на ниска или народна и висока или учена, христијанска (клерикална, латинска), го истакнува антагонизмот меѓу овие две културни матрици. ${ }^{1}$ Таквата поделба е биполарна, така што едниот пол на културата се посматра како инверзија на другиот (Le Goff and Nora 1985). Биполарната структура на културата го свртува вниманието кон антагонизмот меѓу одделните културни обрасци и го претвора дијалогот меѓу нив во конфликт. Како последица на таквиот пристап, антагонизмот претставува основно обележје на средновековната култура. Наместо дијалог, доаѓа до анимозитет меѓу културните обрасци. Секој се затвора во својата култура, контактот е сведен на минимум.

Стратегијата на забрани и култови го поттикнува отпорот и спротивставувањето по секоја цена. Колку повеќе се нагласува каноничноста на црковната култура, толку повеќе се нагласувал карневалскиот карактер на народната култура и нејзината паганска

\footnotetext{
${ }^{1}$ Индивидуалниот вкус, избор и однос спрема културните и естетските стандарди и вредности се одредени од најмалку пет чинители, кои влијаат и врз дихотомијата висока/ниска култура: возраста, класата, религијата, етницитетот, регионалното потекло и образованието, но најдобар индикатор е образованието (Gans 1974).
} 
свест. Фолклорната свест вршела улога на одбрана и напад истовремено. Трагајќи по блиски, ритуални и катарзични облици на култура, народната култура се затвора во просторот на архаичната претхристијанска традиција, на митопоетската слика на свет и на ласцивниот и гротескен реализам во којшто колективот се огледа во единката/човекот, а единката/човекот во колективот.

Народната култура ја надминува дихотомијата меѓу другите два поларизирани културни обрасци, уметничкиот (авторски) и неуметничкиот (колективен). Таа, сфатена како систем на творечки, традициски и комуникациски начела, вклучува и елементи на естетичност. Авторот во усната народна книжевност е само условно отсутен и „мртов“, а всушност е постојано активно присутен во сите фази од создавањето, пренесувањето, изведбата, собирањето и запишувањето на усните народни приказни, епови, песни и др. Естетиката на народната култура, иако неизречена и незапишана, сепак постои во облик на иманентна естетика и поетика. Таа е вградена во самиот фолклорен опус кој е легитимен предмет на проучување на фолклористиката, но влегува и во зоната на истражувачкиот интерес и на други дисциплини (антропологија, етнологија, културологија).

Народната култура се стреми да биде енигматична и делотворна: таа не нуди само предмети за пасивно гледање, туку и услови за активно учество. Живата изговорена реч има(ла) третман на величина од ист ред како постапката (чинодејствието) во рамки на средновековниот учен и народен реализам. Со други зборови, народната култура и на говорот му припишува делотворни, магиски својства. Таа е ритуална култура која има структура на „магиски реализам“: присуство на архаичен поглед на свет во современи околности; висок степен на фантазмагоричност; гротескно пресликување на фантастичното во реалистичнотоили „гротескниот реализам“ кој е проекција на материјално-телесното начело (Bahtin 1978); митски, ониричен, суеверен и сакрален светоглед; „јукстапозиција на фанастичното и на реалистичното“ и воведување „мистериозни и езотерични елементи“ (Тодоровска 2020); чувство на стигматизираност пред туѓото наметнато како свое; култура на смеата (хуморот, комичното, ласцивното), од една страна, и психологија на меланхолија и на трагично чувствување на животот, од друга (жал, тага, носталгија). ${ }^{2}$

Склоноста кон ритуализација кај народната култура е изразена и во современи околности. Тоа е затоа што „наративните традиции им обезбедуваат на луѓето значење и разбирање на нивното постоење,

\footnotetext{
${ }^{2}$ Комичното и трагичното, профаното, пародиското и сакралното се „две страни на едно исто поимање на светот“" (Frejdenberg 1986).
} 
додека ритуалите го зацврстуваат кај луѓето чувството за подлабока припадност и идентитет (Flood 1999: 198). Народната култура има суштински стабилен знаковен и вредносен систем, затоа опстанува низ вековите (Стојановиќ-Лафазановска 2006). Тоа е во сообразност со стабилноста на некои владејачки општествени формации во коишто народната култура доживува процвет (средновековието, феудализмот, византискиот и отоманскиот систем траат со векови), но тоа не објаснува зошто феноменот на народната култура е трансисториски и зошто опстанува во сите епохи од историјата на човештвото. Можеби одговорот треба да се бара во самиот систем на народната култура, во неговата константа која се препознава како почетен модел на фолклорност. Станува збор за оној културен супстрат кој им се спротивставува на ригидните облици на апстрактното мислење, на рационализмот и интелектуализмот. Тој супстрат на народната култура се залага за еден примордијален, имагинарен, фантастичен и метафоричен поглед на свет, кој суштински е сетилен и сликовит, изведбен, сценски, обреден и „конкретен“. Во тоа се состои конститутивната енигматичност на народната култура, она што Олга Фрајденберг го нарекува „иносказание“ (Frejdenberg 1986: 21).

\section{3.}

Во 19 век, кога на Балканот се провлекуваат елементи на доцносредновековие и пост-средновековие, се јавуваат нови околности и се потиснува првичниот биполарен однос меѓу народната и црковната култура. Се воспоставуваат нови односи во културата, препознатливи по зголемената сензибилност за различните културни практики. Во такво цивилизациско опкружување, се јавува потреба од адаптирање, како на христијанската, така и на народната култура.

Од една страна, се создава еден граничен облик на фолклорна култура (Le Goff and Nora 1985). „'Фолклоризираното христијанство' живеело напоредно со магијата и 'анимистичката свест'“ (Gurevič 1987: 335). Содржината на народната култура се слевала, но не се исцрпувала со „атмосферата на сакралното, пренесена низ ритуали и верувања" (Gurevič 1987: 10). При контактот на народната култура со културата на учените и образовани луѓе, дошло до заемно влијание меѓу фолклорните традиции и официјалните црковни доктрини, при што се збиднал т.н. „парадокс на средновековната култура“ (Gurevič 1987: 11). Остатоците од старата култура вршеле нова функција во новиот општествен и културен контекст (Gurevič 1987: 326). Фолклоризмот, сфатен како доминантна културна матрица на 
втората половина на 19 век во Македонија, врши улога на примарен фактор во националното освестување на Македонците, кое доаѓа до израз во нивните јасно искажани културни, јазични и национални политики од крајот на 19 и почетокот на 20 век (Партениј Зографски, Ѓорѓија Пулевски, Крсте Мисирков, Димитрија Чуповски). Фолклоризмот ја претставува граничната линија каде што доаѓа до понагласени македоноцентрични културни, јазични, црковни и национални политички платформи, а од крајот на 19 век и до порадикални национални револуционерни движења, со што се дава јасен одговор на пропагандите за македонско-бугарско и македонско-српско преклопување.

Од друга страна, на општествената сцена се појавува нова граѓанска култура, ни чисто христијанска, ни чисто народна, туку повеќе соодветна на актуелниот градски и буржоаски амбиент: нова градска економска, социјална и политичка елита, западноевропски влијанија во модата, архитектурата и уметноста, нови образовани генерации, нови регионални културни политики (Хан 1988).

Граничните културни практики од втората половина на 19 и почетокот на 20 век, се јавуваат во време на сложени постколонијални процеси: распад на Отоманската империја, создавање мали национални држави, романтичарско-национални идеологии, културна преродба на балканските народи, ослободителни и револуционерни движења, потиснување на феудалниот режим, појава на ран капитализам, обнова на монархизмот, социјално и национално будење, борба за економски, културен и статусен престиж, фрагментација на Балканот, политизација на јавниот дискурс, нови миграции...

Раната македонска граѓанска култура е преоден облик меѓу локалната фолклорна и православна свест и западно-европската буржоаска свест. Граѓанската култура била податлива на надворешни влијанија од соседните балкански култури, што довело до појава на: елинизација (со помош на црковно-клерикалните инсталации и на трговијата каде што преовладувало гркофилството); исламизација (со оглед на моќните отомански центри на моќ); бугаризација (со оглед на масовната миграција на Македонците во Бугарија ${ }^{3}$ и силната и институционализирана бугарска пропаганда) и србизација (со оглед на српската црковна, образовна и политичка пропаганда). Но, и во такви сложени околности, македонската градска култура (Охрид,

\footnotetext{
${ }^{3}$ Миграцијата на Македонците во Бугарија е условена од егзистенцијални причини, кои не се само економски, туку често и борба за опстанок, за „гол живот“, поради конфликтните и тензични состојби во Македонија во периодот на отоманскиот колонијализам, потем заради стекнување образование (затоа што идентитетски се чувствувале поблиски до Бугарите одошто до Грците) и, на крај, затоа што биле подложени на нови идентитетски асимилации, конверзии и пропаганди.
} 
Битола, Струга, Велес, Прилеп) си изградила свој профил, своја препознатливост наспрема соседните културни профили.

Појавата на граѓанската култура веќе е сигнал дека се менуваат општествено-економските околности, дека се ублажил антагонизмот меѓу црковната и фолклорната свест и дека се создале услови за заемно влијание меѓу културните обрасци. Така, се поттикнува појавата на нијансирани културни практики. Црковната се отвора спрема народната во онаа мера во којашто се создава амбиент и народната да се отвори спрема црковната. Во тој процес помага повторното воведување на црковнословенскиот и бугарскиот јазик во богослужбата, а некаде и на македонските локални идиоми. Во споредба со водењето литургија на грчки јазик, овој јазичен пресврт имал револуционерно значење. По укинувањето на Охридската архиепископија (1767), духовниот бунт на македонскиот народ се рефлектирал во народната култура и во усното книжевно творештво. Во тој период се засилува интересот за запишување и проучување на изворното македонско народно творештво, а се појавуваат и народни драми, огледи, автобиографии, историски дела, етнографски прилози, речници, граматики, преводи на светска и световна литература, списанија, проекти за кодификација на македонскиот јазик, устави, повелби, дипломатска активност (Македонското научно-литературно друштво во Петроград, 1902), политички програми и други облици на декларирање на македонскиот културен, јазичен и етнички идентитет.

Културата на македонската Преродба е попрво систем на гранични, одошто на поларизирани културни обрасци. Како што се појавува капитализмот со својата граѓанска класа, така се обликува една специфична граѓaнска култура на фонот на аристократската. Таа (граѓанска) култура има доминантно профан и световен поглед на свет, но содржи и траги од другите културни обрасци. Граѓанската култура е цивилизациски исчекор од традиционалните обрасци на фолклорната, ритуална, мито-поетска и магиска култура, но остава простор за коегзистенција со нив. Македонската граѓанска култура се дистанцирала и од фолклорната, и од црковната културна практика, така што го избегнала грубиот антагонизам. Би можело да се зборува за еден културен триаголник, кој претставувал уводна фаза во преминот кон модерните плурални културни системи.

За лиминалниот карактер на културната свест кај македонските интелектуалци во 19 век сведочи и примерот на Григор Прличев (1974). Тој, иако создава врвни уметнички дела (поемата Сердарот, епот Скендербег), иако се занимава со превод на врвни уметнички дела (Илијада на Хомер, Бесниот Орландо на Лодовико Ариосто), иако е европски образован говорник/оратор и полиглот, отворен спрема 
новите западноевропски текови, се посветува на просветна и дидактичка дејност и културен активизам, во рамки на коишто изведува извонредни реторички сеанси со народот, ја помага фолклористичката дејност, се залага за возобнова на Охридската архиепископија и, сепак, во еден период од својот живот (постелинистичкиот), се обидува да го устрои т.н. општословенски јазичен идиом. Заскитан меѓу јазиците, не познавајќи го добро бугарскиот јазик, а во недостаток на македонски јазични стандарди, прави неуспешен обид за создавање македонско-бугарска норма. Неговиот обид се вклопува во поширокиот општествен амбиент, кога една од опциите за кодификација на бугарскиот и македонскиот јазик била создавањето мешан, „општ“ идиом. Македонските учени, како Партениј Зографски (1858), предлагале тоа да се направи врз основата на југо-западните македонски дијалекти, но бугарските филолози (Марин Дринов 1870) го одбиле тој предлог. Потоа следат самостојни македонски и бугарски проекти за одделна кодификација на македонскиот и бугарскиот јазик (Ќулавкова 2020). Феноменот на граничноста/лиминалноста, значи, е карактеристичен особено за преодните периоди од развојот на културата и општеството, како на поширок, така и на одделен план.

\section{4.}

Да заклучиме. Контактот/дијалогот меѓу културите е важен чинител на развитокот на културите. Не е доволно да се увиди разликата меѓу двете антагонистички културни матрици, треба да се препознаат и споделените места на контакт меѓу разните културни обрасци. Културата, во каков облик и да се практикува, се стреми да воспостави контакт. Таа е иманентно интеркултурна, како што и човекот е суштински интерсубјективен. Културните обрасци се детерминирани од актуелните општествени околности во коишто се вклучени сите носители на културната дејност: творците, изведувачите, публиката, критиката, рецепцијата, сценскиот простор, медиумските канали. Опстанокот на еден културен образец не зависи толку од степенот на антагонизмот спрема културната традиција, колку од подготвеноста за дијалог со наследените, но и со новите културни практики. Антагонизмот, ако успее да ја поттикне критичката свест и самосвест на постојните културни матрици, може да прерасне во потенцијален облик на контакт. А кај што има меѓукултурни контакти, има и изнијансирани и преодни културни обрасци.

Секој културен образец има сопствена гранична зона, чувствителна на граничната зона на другите културни обрасци. Тие гра- 
нични зони се места на контакт меѓу различните културни обрасци и може да имаат развојна улога во развитокот на културите. Од граничните зони произлегува граничната интенција (intentio liminalis) во културно-историскиот развој, која не ги урива постојните обрасци, туку ги модифицира и воведува други, т.н. трети гранични културни идентитети.

Поделбите на културните обрасци во теоријата се релативни, а не исклучиви. Биполарноста на културата се радикализира во некои епохи, но во други се ублажува и се нијансира со нови, преодни, мешани и гранични облици. Неопходно е да се пронајдат местата каде што се одвива процесот на нивното мешање и каде што тие си го модифицираат сопствениот образец со помош на контактот со другиот, спротивен образец. Црковната и граѓанската варијанта на т.н. висока култура не се толку категорично противставени на „ниската“ народна култура (Bahtin 1978). Разликите се неспорни, но, исто така, не е спорно дека и двете практики покажуваат интерес за фолклорот и фолклорната свест и дека се отвораат спрема некои елементи на популарната култура. Таа отвореност на црковната и на граѓанската култура спрема фолклорната создава услови за контакт меѓу нив, а со тоа и за нивна карневализација. Карневализмот претставува константа на културниот систем и одлика на неговата еволуција. Тој е израз на исконскиот човечки револт против табуата и стремежот за слобода, затоа што го претставува другото лице на слободата и ослободувањето од предрасудите, стравот и стигмите. Карневализмот на новите културни обрасци, сфатен како рефлексија на контактот меѓу различните културни практики, но и како порив за ослободување од ограничувачките стереотипи, се повторува низ историјата.

Толкувањето на македонската култура на 19 век ги надминува локалните и биполарни епистемолошки рамки и се упатува кон парадигмата на граничност и мултиполарност. Проблематична е секоја ригидна дихотомија висока/ниска култура, односно поларизацијата на учената, црковна и елитна култура, од една страна, и ниската, народна, фолклорна и масовна култура, од друга. И високата култура е рефлексија на контактот меѓу културните обрасци, но фокусиран врз нивната естетска функција. Поради сето тоа, во категоријата „висока култура“ во 19 век не спаѓа само црковната (учена), ниту само елитниот дел од т.н. граѓанска (староградска) култура, туку и еден дел од фолклорната (култура). 


\section{Библиографија}

Зографски, Партений (1858). Мисли за Болгарски-от Язик. Български книжици, 1, Цариград. Достапно на: http://www.strumski.com/books/PartenijZografski_ Misli_za_Bolgarskiot_Jazik.pdf (5.10.2020).

Петрушевски, Михаил Д. (1969). Македонски препев на Хомеровата Илијада. Скопје: Просвета.

Прличев, Григор (1974). Одломки од Илијадата на Хомер. Во Тодор Димитровски (прир.), Григор Прличев - Одбрани текстови. Скопје: Македонска книга, 49-64.

Стојановиќ-Лафазановска, Лидија (2006). Хоризонти на народната култура. Скопје: Институт за фолклор „Марко Цепенков“.

Тодоровска, Марија (2020). Магиски реализам. Во Катица Ќулавкова (ур.), Поимник на книжевната теорија (во печат). Скопје: МАНУ.

Ќулавкова, Катица (2016). Хибридизација на културните обрасци: пролог кон една гранична, поп-елитна култура. Во Катица Ќулавкова (ур.), Отворена поетика. Скопје: МАНУ, 7-24.

Ќулавкова, Катица (2020). Предисторија на кодификацијата на македонскиот книжевен јазик. Во Катица Ќулавкова (ур.), Македонскиот јазик континуитет во простор и време. Скопје: МАНУ, 21-41.

Хан, Верена (ур.) (1988). Градска култура на Балкану (XV-XIX век) 2. Зборник радова. Београд: Балканолошки институт САНУ. Достапно на: https://dais. sanu.ac.rs/handle/123456789/3945 (3. 10. 2020).

Цепенков, Марко (1972). Македонски народни умотворби I-X. Скопје: Македонска книга.

Bahtin, Mihail M. (1978). Stvaralaštvo Fransoa Rablea i narodna kultura srednjeg veka i renesanse. Prev. T. Vučković. Beograd: Nolit.

Bakhtin, Mikhail M. (1981). The Dialogic Imagination: Four Essays. Ed. Michael Holquist. Tr. C. Emerson and M. Holquist. Austin and London: University of Texas Press.

Bhabha, Homi (1998). The Third Space. Interview with Homi Bhabha. In Jonathan Rutherford (Ed.), Identity: Community, Culture, Difference. London: Lawrence and Wishart.

Flood, Gavin (2006). Beyond Phenomonology: Rethinking the Study of Religion. London, New York: Continuum. Retrieved from: https://books.google.mk/books/ about/Beyond_Phenomenology.html?id=Qt_YAAAAMAAJ\&redir_esc=y $\quad\left(\begin{array}{ll}30 . & 9\end{array}\right.$. 2020).

Frejdenberg, Olga Mihajlovna (1986). Slika i pojam. Prev. M. Medarić. Zagreb: Nakladni zavod Matice Hrvatske.

Gans, Herbert J. (1974). Popular Culture and High Culture: An Analysis and Evaluation of Taste. New York: Basic Books.

Gurevič, Aron (1987). Problemi narodne kulture u srednjem veku. Prev. L. Subotin. Beograd: Grafos.

Le Goff, Jacques and Pierre Nora (Eds.) (1985). Constructing the Past: Essays in Historical Methodology. Cambridge: Cambridge University Press. 
Ruthner, Clemens (2019). Grenzwertig im Dazwischen. Liminalität als DenkRaum. Ars \& Humanitas 13(2). Retrieved from: https://revije.ff.uni-lj.si/arshumanitas/ article/view/8973/8819 (1.10.2020).

\title{
Liminal Cultural Models: The Macedonian $19^{\text {th }}$ Century Paradigm
}

\author{
Katica Ḱlavkova
}

\section{Summary}

Every cultural model has its own border zone, which is susceptible to the border zones of other cultural models. These border zones are places of contact between the divergent cultural models. Cultural history is marked by the constant tension between two principle intentions: 1) to save the archaic substrate of cultural identity (the initial and traditional model), and 2) to carnivalize the canonized cultural model through its contact and intercultural dialogue with other diverse cultural identities and practices. The carnivalizing intention opens the possibility for a third cultural intention that we could name borderline intention or intentio liminalis. It does not destroy the existing models but only modifies them and introduces other liminal - also called "third" - cultural identities.

Culture is immanently intercultural (dialogic), much like people are fundamentally intersubjective (social). Thereby, cultural contact and dialogue are important factors for the development of cultures. Even the antagonism between the different cultural models is a potential form of contact, which means that it generates transitional and borderline cultural models and practices. According to cultural theory, the phenomenon of cultural liminality is particularly characteristic of the transitional periods of development in culture and society. It only appears as categorical and identity confusion, while it, actually, stimulates cultural development and is an important indication for cultural evolution.

Culture in the Macedonian Enlightenment Period is a typical system that is comprised of liminal/borderline cultural models rather than of antagonistic and polarized ones. The cultural paradigm of the $19^{\text {th }}$ century surpasses the local and bipolar theoretical frameworks. It points out the problematic character of the rigid dichotomy of high (sacral) and low (profane) culture. The new Macedonian civic (old-town) culture both incorporated and distanced itself from the church cultural practice and the folklore cultural practice, thus avoiding the rude antagonism. Therefore, in $19^{\text {th }}$ century Macedonia, the category of "high culture" entails not only the (lettered) church culture and the elite part of the so-called civic (old-town) and proEuropean culture, but a part of folklore, as well. The aesthetic quality is what raises the different cultural models to the level of art. Moreover, precisely the folklore culture - the guardian and the transporter of the ancient cultural substrate - denoted the dominant new cultural paradigm (the third culture), which articulated the Macedonian linguistic, civic, church, and even national political priorities. And from the 
end of the $19^{\text {th }}$ century onward, it also stimulated the more radical (national) revolutionary movements.

Keywords: folk culture, contact, carnivalism, intentio liminalis, liminal/borderline models, border zones, third culture, cultural substrate, North Macedonia

\title{
Лиминални културни обрасци (македонската парадигма у 19. веку)
}

\author{
Катища Ћулавкова
}

\section{Резиме}

Сваки културни образац има сопствену граничну зону, осетљиву на граничне зоне других културних образаца. Ове граничне зоне су места додира између различитих културних образаца. Културна историја је обележена постојаном тензијом између две основне интенције: 1) да се сачува архаични супстрат културног идентитета (почетни и традиционални модел), и 2) да се подвргне карневализацији доминантан културни образац путем његовог додира и интеркултурног дијалога с другим културним идентитетима и праксама. Карневализација отвара простор за трећу развојну интенцију, која се може назвати граничном или intentio liminalis. Она не руши постојане обрасце него их мења и уводи „треће“ граничне културне идентитете.

Култура је иманентно интеркултурна (дијалошка), као што је и човек у основи интерсубјективан (комуникативан, социјалан). Културни контакт и дијалог су важни чиниоци развитка културе. Чак и антагонизам међу различитим културним обрасцима је потенцијални облик контакта, што значи да он ствара прелазне и граничне културне обрасце и праксе. Према културној теорији, феномен граничности/лиминалности је карактеристичан нарочито за прелазне периоде развоја културе и друштва. Лиминалност ствара привид категоријалне и идентитетске конфузије, али заправо подстиче културни развој и представља важан показатељ културне еволуције.

Култура македонског препорода је пре свега систем граничних, а не поларизованих културних образаца. Македонска култура 19. века надилази локалне и опречне теоријске оквире. То указује на проблематику круте дихотомије висока - ниска култура. Нова грађанска култура је интегрисала фолклорну и црквену културну праксу али се уједно и дистанцирала од њих тако што је избегла груби антагонизам. Зато у категорију „високе културе“ у Македонији 19. века не спадају само црквена (учена) култура, нити само елитни део тзв. грађанске (варошке) културе, него и један део фолклорне културе. Управо естетски квалитет издиже различите културне обрасце на раван уметности. Уз то, фолклорна свест, а с њом и фолклорни културни образац постају чувари и преносиоци древног културног супстрата, и то обележава преовлађујућу нову 
културну парадигму (трећа култура), која је артикулисала македонске језичке, црквене, па и националне политичке приоритете, а од краја 19. века побудила је радикалније револуционарне покрете.

Кључне речи: народна култура, фолклоризам, карневализација, intentio liminalis, лиминални обрасци, граничне зоне, трећа култура, културни супстрат, Северна Македонија

Катица Ќулавкова

Македонска академија наука и уметности,

Скопље, Северна Македонија

Филолошки факултет, Универзитет „Св. Кирил и

Методиј“, Скопље, Северна Македонија

Примљено: 6. 10. 2020.

Е-пошта: kulavkova@manu.edu.mk

Прихваћено: 26. 12. 2020. 